
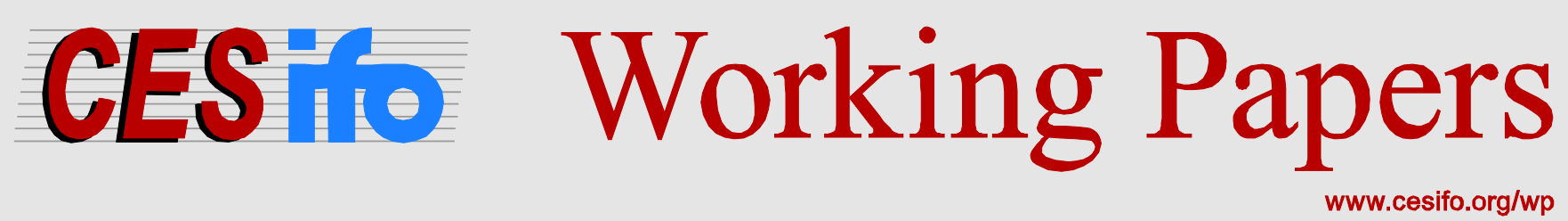

\title{
When will there be Gift Exchange? Addressing the Lab-Field Debate with Laboratory Gift Exchange Experiments
}

\author{
Judd B. Kessler
}

CESIFO WORKING PAPER NO. 4161

CATEGORY 13: BEHAVIOURAL ECONOMICS

MARCH 2013

Presented at CESifo Area Conference on Behavioural Economics, November 2012

An electronic version of the paper may be downloaded

- from the SSRN website:

- from the RePEc website:

- from the CESifo website:

WWW.SSRN.com

www.RePEc.org

www.CESifo-group.org/wp

\section{CESifo}




\title{
When will there be Gift Exchange? Addressing the Lab-Field Debate with Laboratory Gift Exchange Experiments
}

\begin{abstract}
Gift exchange experiments have demonstrated that norms can affect labor market outcomes and provided an explanation for involuntary unemployment. However, conflicting results from laboratory and field experiments have questioned the relevance of gift exchange and helped spark an ongoing debate about the relative merits of the lab and field. This paper uses laboratory experiments to identify three parameters that affect the likelihood workers engage in gift exchange, helping to reconcile results across lab and field experiments. Gift exchange is more prevalent when workers are rich relative to the firm, worker effort is efficient, or workers have a restricted action space.
\end{abstract}

JEL-Code: C900, D210, J300.

Keywords: experimental economics, laboratory experiments, gift exchange, reciprocity.

\author{
Judd B. Kessler \\ The Wharton School \\ University of Pennsylvania \\ 3620 Locust Walk \\ 1454 Steinberg Hall-Dietrich Hall \\ USA - Philadelphia, PA 19104 \\ judd.kessler@wharton.upenn.edu
}

This Draft: February 26, 2013

I am grateful for advice and guidance from Alvin Roth, financial support from the National Science Foundation and Harvard Business School, support from the CLER staff, as well as suggestions and comments from Gary Charness, Lucas Coffman, David Huffman, Stephen Leider, Adi Sunderam, Muriel Niederle, Lise Vesterlund, Christian Zehnder, seminar participants at ESA conferences in Rome (2007) and Tucson (2007, 2008, 2009), and seminar participants at Harvard University, the University of Pittsburgh, and the CESifo Area Conference in Behavioral Economics 2012 in Munich. 


\section{Introduction}

Within economics, a debate about the relative merits of laboratory and field experiments has flared over the past decade. Vocal critics of the lab argue that laboratory experiments may not generalize to "real world" environments, making it difficult to draw inferences from laboratory games to economic markets of interest. These authors point to differential treatment effects across the lab and the field to demonstrate a lack of generalizability of laboratory findings (Harrison and List 2004; Levitt and List 2006, 2007a, 2007b, 2008; Al-Ubaydli and List 2012). Proponents of the lab argue that field experiments are subject to the same weakness: results from one particular field setting may not generalize to other field settings, suggesting that the field is simply a different environment, without any special status, in which to look for treatment effects (Falk and Heckman 2009, Kagel 2009, Camerer 2012). ${ }^{1}$

Throughout the debate, gift exchange has been a central example emphasized by authors on both sides (see for examples Levitt and List 2007a, Falk and Heckman 2009, Kagel 2009) in part because of the importance of gift exchange as an example of the role norms can play in labor market outcomes (see Akerlof 1982, Akerlof and Yellen 1990) ${ }^{2}$ and in part because gift exchange results measured in the laboratory and in field have been shown to differ drastically.

Laboratory tests of gift exchange involve a first mover (a "firm") making a transfer (a "wage") to a second mover (a "worker"), who is then given the opportunity to make a transfer back ("effort") to the first mover, after which the game ends. ${ }^{3}$ Laboratory experiments routinely

\footnotetext{
${ }^{1}$ Most recently, Camerer (2012) systematically addresses the five differences that Levitt and List (2007a) highlight between lab and field to demonstrate that they have less of an impact on results than Levitt and List suggested. Al-Ubaydli and List (2012) argue for the superior generalizability of field experiments by developing a model of generalizability and assuming that laboratory experiment settings are further from natural settings of interest than field experiment settings.

${ }^{2}$ Gift exchange experiments are meant to test the gift exchange and fair wage-effort models of the labor market (Akerlof 1982, Akerlof 1984, Akerlof and Yellen 1990). These theories argue that employers have an incentive to pay employees a price above the market-clearing wage in order to generate higher effort from their workers. The gift exchange theory does not rely on monitoring and punishment of shirking. Instead, it argues that there exists a social norm for gift exchange such that the receipt of a gift generates a desire to reciprocate. It implies that when employers pay a wage higher than the market-clearing wage-a gift for the worker - the worker will exert more effort - a gift for the employer. Akerlof and Yellen (1990) present the theory in terms of a fair-wage hypothesis, arguing that workers will exert less effort if they are paid a wage below their perceived fair wage, which is determined by previous wages, the wages of comparable workers, and the unemployment rate, among other factors.

${ }^{3}$ Most laboratory experiment designs have subjects play the game multiple times with random rematching of firms and workers and subject anonymity to mitigate potential strategic concerns of repeated play. One or both of the transfers is scaled to make the transfers socially efficient.
} 
find that experimental workers respond to high wages by providing high effort (early examples include Fehr, Kirchsteiger and Riedl 1993; Fehr, Gachter and Kirchsteiger 1997; Fehr et al. 1998; Charness 2000; Gachter and Falk 2002; Hannan, Kagel and Moser 2002; Charness 2004; Charness, Frechette and Kagel 2004; Brandts and Charness 2004; for a review, see Fehr, Goette and Zehnder 2009).

Field studies of gift exchange generally take place in field environments where worker productivity is measurable and where workers can be treated with exogenous positive wage shocks. ${ }^{4}$ These experiments find mixed results for gift exchange. In certain environments, workers produce more in response to unexpected, short-term increases in pay (Cohn, Fehr and Goette 2008, Bellemare and Shearer 2009, the bonus treatment in Englmaier and Leider 2012; see Falk 2007 for evidence of gift exchange in charitable giving). In other environments, cash gifts fail to generate extra productivity, while in-kind gifts succeed in doing so (Kube, Marechal and Puppe 2011). Other settings generate transient evidence of gift exchange, for a short while after an increased wage is announced (the data entry task in Gneezy and List 2006). Finally, some field settings generate no evidence of gift exchange (List 2006; the door-to-door fundraising task in Gneezy and List 2006; Hennig-Schmidt, Rockenbach and Sadrieh 2010; the no bonus treatment in Englmaier and Leider 2012).

In this paper, I aim to help explain the differential results on gift exchange found across laboratory and field experiments and to address the laboratory and field debate while doing so. This paper presents the results of two laboratory gift exchange experiments. The first investigates two parameters that systemically differ between many laboratory and field experiments on gift exchange: the relative wealth of firms and workers, and the efficiency of worker effort. I test whether each of these parameters could contribute to variation in previously observed gift exchange results. The second experiment investigates the role of another parameter: the action space of the worker.

Each experiment demonstrates that when the parameters of the gift exchange game change, the extent of gift exchange observed changes. When either: firms are made richer than workers (Experiment 1), worker effort is less efficient (Experiment 1), or workers action space allows them to take advantage of the firm (Experiment 2), the likelihood that workers engage in

\footnotetext{
${ }^{4}$ There is a related gift exchange literature looking at wage cuts on effort, which consistently finds a decrease in effort in response to a surprise decrease in wages.
} 
gift exchange diminishes, at least somewhat. Since these parameters differ systematically across laboratory and field settings, the findings help to reconcile differential gift exchange results.

In reconciling gift exchange results, the findings implicitly challenge the presumption that variation in results between lab and field are due primarily to differences between the traditional lab experiment and the traditional field experiment (e.g. the selection of subjects into the experiment, the stakes, the role of experimenter scrutiny, the duration of the game) that have been the focus of the ongoing debate. ${ }^{5}$ These differences between traditional laboratory and field experiments may not be the reason that treatment effects vary from a particular lab setting to a particular field setting. Instead, the relevant differences may be about other game parameters.

I am by no means the first to attempt to explain why gift exchange results differ across settings. One way to address this discrepancy in results is to conduct similar experiments in a number of environments, which include both the laboratory and field settings of interest. List (2006) provides a prime example of this strategy as well as one of the early revelations that gift exchange may not be observed in field settings. List (2006) observes gift exchange among sports card buyers and sellers is a laboratory experiment but does not find gift exchange among the same population when they play a similarly structured game outside of the lab (i.e. in the sports card market without observable experimenter scrutiny). These results demonstrate how gift exchange can vary across settings, and List (2006) describes the care involved in selecting a field setting that looks similar to the laboratory on many important dimensions. One limitation of this approach, however, is that even with care in selecting the field setting, a number of factors change as we move from the laboratory to the field. The move from the lab to field removes observable experimenter scrutiny, but it also changes: (1) the information that players have about the setting, (2) the rules of the game, and (3) the action spaces available to the players. While the List (2006) series of experiments clearly show us that gift exchange changes with the environment, is raises the question of why the results change. Without knowing what factor or factors led to the differential results between the lab and field, it is impossible to know whether a different field setting will display results more like the lab or more like the field.

\footnotetext{
${ }^{5}$ I reference these differences as being associated with the "traditional" lab and field experiments as it is often possible to eliminate these differences in the lab (e.g. by changing the subject pool being recruited, the stakes they face, the extent of experimenter scrutiny, and the length of the experiment). Selection into the study is an interesting research topic in its own right (see e.g. Slonim et al. 2012).
} 
The technique used in this paper is also distinct from the strategy, as proposed in Camerer (2012) and elsewhere, of addressing differential treatment effects by running laboratory environments that more closely mirror a field environment of interest. While such an approach may also be a fruitful avenue to pursue, it poses a similar challenge of identifying all of the ways that two settings differ and being selective about the factors that are adjusted to make the laboratory look more like the field.

By contrast, the laboratory experiments described in this paper were designed with features - like a random outcome that is revealed between the wage setting and the effort provision - that make the experimental setting look less like field environments outside the lab. This design choice allows for an analysis of specific parameters that might affect gift exchange while holding other factors constant. The random outcome in Experiment 1 allows for a test of how firm wealth impacts gift exchange without confounding the perceived generosity of the wage. ${ }^{6}$ In this case, that the laboratory looks different from the field is a strength, rather than a weakness, of the laboratory.

The results generated by this method - varying the parameters of an environment to look for changes in a treatment effect - make comparative static predictions about where gift exchange will be stronger and where it will be weaker. ${ }^{7}$ Fortunately, there has been little-to-no disagreement that comparative static (i.e. directional) effects identified in the lab translate well to settings outside of the lab (Kessler and Vesterlund 2012).

This approach - investigating how changes in parameters of the game change the magnitude (or direction) of a treatment effect - is one of the foundations of the experimental methodology within economics, and it is not unique to the laboratory. Additionally, conducting a study completely in the laboratory to investigate why lab and field results differ is by no means a

\footnotetext{
${ }^{6}$ In contrast, Xiao and Bicchieri (2010) describes a laboratory trust game that includes a treatment in which investors (i.e. firms) are initially richer than their trustees (i.e. workers), such that after an initial transfer the two groups have the same experimental earnings. Return transfers are smaller when the firm and worker have the same experimental earnings than when the firm is poor relative to the worker. This design, however, allows firm wealth and the intentions associated with trusting to move together. Consequently, we do not know if transfers to rich firms are smaller because of the wealth effect or because the wage is interpreted as more generous when the firm is poor. Here we investigate how workers respond to a variety of wages when the firm is richer than the worker and conclude that firm wealth affects the extent of gift exchange, keeping employer wage intentions constant.

${ }^{7}$ Hennig-Schmidt, Rockenbach and Sadrieh (2010) take a similar approach and is discussed in further detail in the section on Experiment 1.
} 
challenge to field experiments. Rather, this paper suggests a particular way in which laboratory and field experiments are complements in the production of knowledge. In particular, field experiments have the potential to identify settings where treatment effects differ significantly from treatment effects found in the laboratory. These field settings are likely complex environments that differ from the laboratory on a variety of dimensions. When field experiments uncover treatment effects that differ from those found in the lab, we can return to the lab to investigate individual parameters that differ between the laboratory and field and might generate the differences in results. Using both methodologies, researchers can come to better understand the underlying mechanisms driving behavior in the lab and the field.

In advocating for this complementarity between laboratory and field research, I join a plurality of researchers - spanning the both sides of the debate - who agree that laboratory experiments and field experiments can complement one another (see Levitt and List 2007a,b; List and Reiley 2008; Roth 2008; Falk and Heckman 2009; Kagel 2009; Hennig-Schmidt, Rockenbach and Sadrieh 2010; Roth 2012; Al-Ubaydli and List 2012; Camerer 2012; Kessler and Vesterlund 2012).

\section{Experiment 1: Firm Wealth and the Efficiency of Effort}

Experiment 1 is motivated by two parameters that systematically differ between almost all laboratory gift exchange experiments and many gift exchange experiments run in the field: the relative wealth of the firm and worker and the efficiency of worker effort.

In almost all previous laboratory studies of gift exchange, subjects in the role of the firm are poor relative to subjects in the role of the worker at the time of effort provision ${ }^{8}$ and worker effort is efficient (in that it increases the social surplus for the firm and worker). ${ }^{9}$ Consequently,

\footnotetext{
${ }^{8}$ For example, Fehr, Kirchsteiger and Riedl (1993) allow firm wages to be between 30 and 130, and the worker is at an experimental unit advantage for any wage larger than 35 . They report that the average wage across all sessions is 72 . The payoffs are calculated for the worker as $\mathrm{u}=\mathrm{w}-26-\mathrm{m}(\mathrm{e})$ and for the firm as $\Pi=(126-w)$ e. After a wage of 72 , the worker has 46 experimental units and the firm has 5.4 experimental units, unless the worker makes a positive return gift (without any return gift, $\mathrm{e}=0.1$ and $\mathrm{m}(\mathrm{e})=0$ ). The majority of laboratory experiments on gift exchange have adopted similar parameters. ${ }^{9}$ It many experimental settings, return gifts are scaled linearly by a factor of five (Brandts and Charness 2004) or contribute to a multiplicative scalar of firm endowment (Fehr, Kirchsteiger and Riedl 1993; Fehr et al. 1998; Charness 2000; Charness 2004; Charness, Frechette and Kagel 2004). There has been some previous research varying the efficiency of effort within gift exchange environments. Hannan, Kagel and Moser (2002) vary the productivity of effort in a gift exchange setting using costs of effort similar to Fehr, Kirchsteiger and Riedl (1993) and find it does not influence patterns of laboratory gift exchange. In
} 
after the firm makes a wage transfer to the worker, the worker is relatively rich, which generates an inequity aversion motive to returning effort - a motive that is stronger the larger the initial wage $^{10}$ — and eliminating this inequity is relatively cheap given the efficiency of worker effort.

These previous laboratory experiments routinely find evidence of gift exchange. In field experiments on gift exchange, however, there is variation in whether firms are likely to be perceived as rich relative to workers and whether worker effort is likely to be perceived as efficient. The observation motivating the design of Experiment 1 is that variation in the perception of firm wealth and variation in the perception of the efficiency of worker effort appear to correlate with the strength of gift exchange observed across experimental settings.

Table 1 provides a list of experiments and settings within experiments that motivate this experimental design, classifying settings based on whether the firm in the experiment is likely to be perceived as poor or rich and whether worker effort in the experiment is likely to be perceived as efficient or not efficient. For the laboratory experiments, this classification can be achieved by simply looking at payoffs. Since field settings are more complex, however, classifying field experimental settings as those in which workers are likely to perceive the firm as rich and those in which workers are likely to perceive their effort as neutral or inefficient is necessarily subjective and open to interpretation.

The bold citations - those that find significant positive evidence of gift exchange - lie primarily in the top left cell of Table 1, and fewer citations in the right column and in the bottom row are bold. A reading of this previous literature suggests that we are more likely to observe gift exchange when firms are poor relative to workers and when worker effort is efficient - as in most laboratory experiments and some field experiments - and we are less likely to observe gift

their experiment, however, almost all wages lead to an environment where effort is efficient. In addition, their design made certain firms more productive and certain firms less productive, which confounds the pure effect of efficiency of effort with firm wealth and intentions of wage offers. The experiment presented here investigates the effect of efficiency isolated from other forces.

${ }^{10}$ Fehr and Schmidt (1999) use experimental gift exchange results as an illustrative example for their model of inequity aversion. Other studies have highlighted that inequity aversion provides a reason for workers to return effort to firms in the lab. Some have kept relative endowments across conditions constant to isolate the effect of firm intentions on effort. Charness (2004) compares worker effort in response to wages determined exogenously (by random process or the experimenter) and wages chosen by a firm. Similarly isolating the effect of intentions of firm wage, Charness and Levine (2007) randomly manipulates firm wages so that workers receive the same wage from firms with different intentions and finds that firm intentions matter significantly. In contrast to these studies, the experiment here keeps firm intentions constant to isolate the role of firm wealth on worker effort. 
exchange when either the firm is rich relative to the worker or when effort is likely to be perceived as neutral or inefficient.

Table 1: Classification of Selected Laboratory and Field Experiments on Gift Exchange

\begin{tabular}{|c|c|c|}
\hline & Firm Perceived as Poor & Firm Perceived as Rich \\
\hline $\begin{array}{l}\text { Worker } \\
\text { Effort } \\
\text { Perceived } \\
\text { As } \\
\text { Efficient }\end{array}$ & $\begin{array}{l}\text { Fehr, Kirchsteiger and Riedl (1993) } \\
\text { Fehr, Gachter and Kirchsteiger (1997) } \\
\text { Fehr et al. (1998) } \\
\text { Charness (2000) } \\
\text { Gachter and Falk (2002) } \\
\text { Hannan, Kagel and Moser (2002) } \\
\text { Charness (2004) } \\
\text { Charness, Frechette and Kagel (2004; } \\
\text { no payoff table) } \\
\text { Brandts and Charness (2004) } \\
\text { List (2006; lab experiments) } \\
\text { Falk (2007) }\end{array}$ & $\begin{array}{l}\text { List (2006; field experiment) } \\
\text { Gneezy and List (2006; data entry) } \\
\text { Cohn, Fehr and Goette (2008) } \\
\text { Bellemare and Shearer (2009) } \\
\text { Hennig-Schmidt, Rockenbach and } \\
\text { Sadrieh (2010; data entry) } \\
\text { Hennig-Schmidt, Rockenbach and } \\
\text { Sadrieh (2010; folding info } \\
\text { treatment) } \\
\text { Kube, Marechal and Puppe (2011; in- } \\
\text { kind gift) } \\
\text { Kube, Marechal and Puppe (2011; } \\
\text { monetary gift) } \\
\text { Englmaier and Leider (2012; bonus } \\
\text { treatment) }\end{array}$ \\
\hline $\begin{array}{l}\text { Worker } \\
\text { Effort } \\
\text { Perceived } \\
\text { As Not } \\
\text { Efficient }\end{array}$ & $\begin{array}{l}\text { Charness, Frechette and Kagel (2004; } \\
\text { payoff table) } \\
\text { Gneezy and List (2006; door-to-door } \\
\text { fundraising) }\end{array}$ & $\begin{array}{l}\text { Hennig-Schmidt, Rockenbach and } \\
\text { Sadrieh (2010; folding no info } \\
\text { treatment) } \\
\text { Englmaier and Leider (2012; no bonus } \\
\text { treatment) }\end{array}$ \\
\hline
\end{tabular}

Bold indicates that the experiment found a significant positive effect of gift exchange.

Along with the laboratory experiments, which find robust evidence of gift exchange when firms are relatively poor and worker effort is efficient, Falk (2007) observes gift exchange in a charitable giving setting. In Falk (2007), "firms" are poor street children in Dhaka, Bangladesh who send a gift of postcards to "workers" who are relatively wealthy potential donors in Zurich, Switzerland. In Falk (2007) we expect workers to perceive the street children to be relatively poor and for worker effort to be perceived as efficient in that potential donors are likely to think that a monetary transfer from a rich donor in Zurich to poor street children in Dhaka generates significant social surplus.

In other field experiment settings, workers are likely to perceive the firm as rich. In these settings, we often do not observe gift exchange. List (2006) does not observe gift exchange when firms are hobbyists buying cards at a sports card convention — enjoying leisure and spending 
disposable income on their hobby — and workers are sellers at the same convention who are there to earn a living. Gneezy and List (2006) do not observe gift exchange from a surprise positive wage shock to students whose effort benefits a university library system. The university, the library, and the salaried employees working there are likely to be perceived as rich by the student workers making an hourly wage. Kube, Marechal and Puppe (2011) also have students work for a university library and do not observe gift exchange from a $20 \%$ wage increase. ${ }^{11}$ Hennig-Schmidt, Rockenbach and Sadrieh (2010) do not observe gift exchange in a similar dataentry task in which workers are employed by a University research institution. ${ }^{12}$

In a field experiment setting where workers are very unlikely to perceive their effort as efficient, we do not observe gift exchange, even though the firm might be perceived as poor. Gneezy and List (2006) does not find gift exchange among subjects who solicit donations for a charity by going door-to-door. These solicitors generate donations that are on average less than their wage over the same time period and so we might think workers are unlikely to perceive their effort as efficient. ${ }^{13}$

Some gift exchange experiments have varied features of the experimental setting and looked for differences in the strength of gift exchange. I describe those experiments here and explain why different settings from the same experiment may fall into different cells of Table 1 .

Englmaier and Leider (2012) vary whether a manager informs employees that he gets a bonus if the employees reach a productivity target in their data entry task. The authors only observe gift exchange when the employees know about the bonus. The manager announcing his bonus establishes a direct benefit for the manager from worker effort, so the change can be interpreted as increasing the perceived efficiency of effort, both because subjects may care about

\footnotetext{
${ }^{11}$ Kube, Marechal and Puppe (2011) finds gift exchange when workers receive an equivalently valued inkind gift.

${ }^{12}$ Certainly, gift exchange is sometimes observed — at least among certain sub-groups of subjects — in settings where we might expect workers to think of firms as being relatively rich (e.g. Cohn, Fehr and Goette 2008 where employees work for a publishing house launching a new newspaper and Bellemare and Shearer 2009 where employees work for a tree-planting firm that received a bonus from the government).

${ }^{13}$ In labor market environments we expect worker effort to be efficient on average (if it were not, the firm could not profitably compensate workers for their effort). In certain field settings, however, additional effort may not be efficient (e.g. worker effort may already be close to the first best). Additionally, a particular field setting created for an experiment may not provide the opportunity for efficient production.
} 
the welfare of the manager or because the existence of the bonus signals something about the value of the data entry task.

Hennig-Schmidt, Rockenbach and Sadrieh (2010) vary whether workers folding envelopes in a real-effort laboratory experiment know the market price for having envelopes folded. When the workers are uninformed about the price, the authors do not observe gift exchange from a $10 \%$ wage increase. When workers are informed about the price, the same $10 \%$ wage increase generates higher productivity. The authors interpret the relevant change as surplus information becoming available and argue that information about the surplus being created must be available for gift exchange to be present. However, the relevant change may have been making workers perceive their effort as more valuable to the experimenter and thus more efficient. The experimental data in Hennig-Schmidt, Rockenbach and Sadrieh (2010) suggests that price information impacts beliefs about the efficiency of worker effort. In the initial work phase, when everyone is being paid the same wage, workers who receive the information produce $13 \%$ more envelopes than workers who do not receive the information. ${ }^{14}$

Charness, Frechette and Kagel (2004) finds less gift exchange in a laboratory experiment in which workers are provided with a payoff table with possible combinations of wages and effort. This difference is driven by lower effort response to the highest wages offered in the experiment. In Charness, Frechette and Kagel (2004), worker effort is less efficient when wages are higher, so providing the payoff table to workers may serve to highlight the lower efficiency of worker effort at higher wages, leading to less gift exchange at high wages.

The relative wealth of the firm and worker and the efficiency of worker effort are parameter differences that vary between laboratory experiment settings and field experiment settings. The summary of gift exchange results above suggests that these parameter differences may contribute to the variation in results between previous laboratory and field experiments. To test this hypothesis, Experiment 1 manipulates these parameters to directly identify their impact on gift exchange results. In some conditions of the experiment, the firm is rich relative to the worker; in others, the firm is poor relative to the worker. In some conditions of the experiment, worker effort is efficient; in others, it is not. The experiment compares the effort-wage

\footnotetext{
${ }^{14}$ This difference is calculated from Table 5 in Hennig-Schmidt, Rockenbach and Sadrieh (2010) and is based on the pre-treatment round, before some subjects receive a higher wage as a gift. Data provided by the authors finds this difference to be marginally statistically significant (OLS with robust standard errors, 56 observations, $\mathrm{p}=0.085$ ).
} 
relationship across conditions. Results are consistent with the pattern in Table 1. Gift exchange is significantly diminished when the firm is richer than the worker and it is somewhat diminished when worker effort is neutral rather than efficient.

\section{Design of Experiment 1}

Experimental participants play 24 rounds of a bilateral gift exchange game as either a firm or a worker. ${ }^{15}$ Each participant is randomly re-matched with a player of the other type in each round so that he never plays with the same participant twice in a row. The experiment lasted one hour, participants were paid for one randomly selected round, and average earnings were \$20.60 per participant inclusive of a $\$ 10$ show up fee. The experiment was designed and conducted using z-Tree 2.1.4 (Fischbacher 2007).

At the start of each round, the firm has 30 units and the worker has 35 units. ${ }^{16}$ Each round consists of three stages. In the first stage, the firm chooses a wage of 0,5 or 10 units, which is multiplied by 4 and transferred to the worker (so the worker receives 0,20 or 40 units). ${ }^{17}$ In the second stage, a random outcome determines whether the firm receives an additional 60 units (is "Rich") or 0 units (is "Poor") and whether worker effort is efficient, so the number of units of effort chosen by the worker is multiplied by 4 ("4-to-1") before it is transferred to the firm, or worker effort is not efficient, so units of effort are transferred without being scaled ("1-to-1"). At the start of the experiment, participants were told that the four possible realizations of the random outcome were equally likely. ${ }^{18}$ Both the firm and worker are informed of the results of the random outcome. The parameters of the experiment are such that if the firm receives 60 units, he has more experimental units than the worker at the end of the second stage, regardless of the wage. ${ }^{19}$ In the third stage, the worker chooses an effort level — any whole number of units

\footnotetext{
${ }^{15}$ Instructions framed the game in a neutral way. Subjects were either a "first mover" or "second mover" and chose whether to "transfer" their "experimental units."

${ }^{16}$ Each experimental unit is worth $\$ 0.20$. The experiment has an initial asymmetry to discourage subjects from thinking of the game as one where they were meant to equalize payoffs and to give the worker more experimental currency that the firm in the baseline case.

${ }^{17}$ The scale factor of 4 for the wage was meant to encourage positive wages in the first stage and to allow for sizeable transfers to workers without giving the firm a significantly larger initial endowment.

${ }_{18}^{18}$ All subjects faced the same random drawing realization.

${ }^{19}$ A firm providing the maximum wage of 10 units in the first stage and receiving 60 units in the second stage would have 80 experimental units to the worker's 75 units. The difference between firm and worker units at the start of the third stage is larger when the firm chooses a smaller wage.
} 
between 0 and 10 - and that number of units is subtracted from his payoff. This number of units is multiplied by 1 or 4 , as determined by the random outcome, and transferred to the firm.

Payoffs to the firm and worker are determined by:

$$
\begin{aligned}
& \pi_{f}=30-w+60 \cdot R+T \cdot e \\
& \pi_{w}=35+4 w-e
\end{aligned}
$$

where:

$\pi_{f}$ is the firm payoff

$\pi_{w}$ is the worker payoff

$w$ is the wage chosen by the firm where $w \in\{0,5,10\}$

the random outcome determines $R \in\{0,1\}$ with $P[R=1]=0.5$

$$
\text { and } T \in\{1,4\} \text { with } P[T=4]=0.5
$$

$e$ is the effort provided by the worker, where $e \in\{0,1, \ldots, 9,10\}$

The wage choice of the firm is made before the random outcome is realized so that the worker's judgment about the "generosity," "fairness," or "intention" of a particular wage is identical across the four conditions. Notice that this allows for an identification of the pure effect of relative wealth and the pure effect of the efficiency of worker effort on the relationship between wage and effort without introducing a confound of a change in the intentions of the firm

\begin{tabular}{|c|c|c|c|}
\hline \multirow{2}{*}{\multicolumn{2}{|c|}{$\begin{array}{c}2 \times 2 \\
\text { Design }\end{array}$}} & \multicolumn{2}{|c|}{ Firm Wealth } \\
\hline & & Poor & Rich \\
\hline \multirow{2}{*}{ 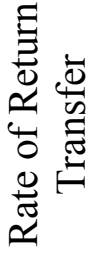 } & 4-to-1 & Poor, 4-to-1 & Rich, 4-to-1 \\
\hline & 1 -to-1 & Poor, 1-to-1 & Rich, 1-to-1 \\
\hline
\end{tabular}
that choses a particular wage.

Figure 1: Four Conditions of Experiment 1 (2x2 Design) 
The experiment has a two-by-two, within-subject design. After the firm choses the wage, the random outcome places the worker in one of the four conditions as shown in Figure 1. The design of the experiment embeds as one of the conditions traditional bilateral gift exchange ("Poor, 4-to-1") and embeds as one of the conditions a trust game ("Poor, 1-to-1"), with parameters similar to other experiments. ${ }^{20}$ Since firms are restricted to choosing a wage of 0,5 or 10 units in the first stage of the game, workers find themselves in one of 12 possible scenarios in each round. Each round, the firm pays a wage of 0, 5, or 10 units (i.e. the worker receives 0,20 or 40 units) and one of the four conditions in Figure 1 is realized. The worker then makes an effort choice for that round in response to the particular wage and random outcome realization.

When we look for evidence of gift exchange — and in particular when we investigate how gift exchange changes as a result of changing the parameters of the experiment — we will look at two related measures of gift exchange. First, we will look at how much more likely workers are to return positive effort when the wage they receive is positive than when the wage is 0 units. This is a natural measure of gift exchange since it asks whether participants in the role of worker are more willing to sacrifice to benefit the firm when the firm gives them a positive wage. This binary measure must be positive for a researcher to have a chance of observing gift exchange in a field setting. We need to look at the difference in the probability of returning positive effort between workers who receive a wage of 0 and workers who receive a wage of 5 or 10 - some workers might be motived to provide effort to a firm who has provided a wage of 0 units (e.g. due to altruism, inequity aversion when the firm is poor, or a surplus seeking motive when worker effort is efficient). If workers are engaging in gift exchange, however, we should see workers return positive effort more often in response to positive wage (of 5 or 10 units) than in response to a wage of 0 units. Second, we will look gift exchange as measured by the slope of at the magnitude of effort ( 0 to 10 in the experiment) with respect to wage $(0,5$ or 10 in the experiment). If either of these measures changes as we change the parameters of the experiment, we will say we have observed a change in gift exchange.

\footnotetext{
${ }^{20}$ Brandts and Charness (2004) use a scale factor of 5 for both wage and effort; the "Poor, 4-to-1" condition uses 4 for both wage and effort. Berg, Dickhaut and McCabe (1995) use a scale factor of 3 for wage and 1 for effort, the "Poor, 1-to-1" condition uses 4 for wage and 1 for effort. Experimental instructions and materials are attached as Appendix A.
} 


\section{Results of Experiment 1}

The experimental results reported here are from 88 participants, students from Bostonarea colleges and universities who participated in five sessions $(n=20,20,18,16,14)$ at the Computer Lab for Experimental Research at Harvard Business School.

In investigating our two measures of gift exchange, we look first at the probability of providing positive effort in response to a positive wage and how it varies with the parameters of the game. Results 1 and 2 speak to how much more likely workers are to provide positive effort when they receive a positive wage of 5 or 10 rather than a wage of 0 .

\section{Result 1 - A positive wage is associated with a larger increase in the probability of positive effort when the firm is poor (more gift exchange when the firm is poor)}

\section{Result 2 - A positive wage is associated with a larger increase in the probability of positive effort when worker effort is efficient (more gift exchange when worker effort is efficient)}

Table 2 reports the probabilities of positive effort by condition and wage. The probability that the worker provides positive effort increases much more in response to a positive wage when the firm is poor (Column 1) than when the firm is rich (Column 2). As shown in Column 1, when the firm is poor the probability of positive worker effort increases 46 percentage points (from $7 \%$ when the wage is 0 to $53 \%$ when the wage is 5 or 10 ). As shown in Column 6 , when the firm is rich, the probability of positive effort only increases 20 percentage points (from $3 \%$ to $23 \%$ ). This difference-in-differences of 26 percentage points - as shown in the bottom row of Column 3 - is statistically significant $(\mathrm{p}<0.001, \mathrm{n}=1056$, OLS with standard errors clustered at subject level).

As with the relative wealth of the firm, the efficiency of worker effort influences the likelihood a worker provides positive effort in response to a positive wage. The probability of positive effort increases more in response to a positive wage when effort is efficient (Column 4) than when it is not efficient (Column 5). As shown in Column 4, when effort is efficient (4-to-1), the probability of positive worker effort increases 37 percentage points (from $7 \%$ when the wage is 0 to $44 \%$ when the wage is 5 or 10). As shown in Column 5, when effort is not efficient (1-to1), the probability of positive effort only increases 29 percentage points (from over $3 \%$ to under 
$33 \%$ ). This difference in differences of 8 percentage points - as shown in the bottom row of Column 6 - is statistically significant at the $10 \%$ level $(\mathrm{p}=0.061, \mathrm{n}=1056$, OLS with standard errors clustered at subject level).

Table 2: Probability of Positive Effort by Condition and Wage in Experiment 1

\begin{tabular}{|c|c|c|c|c|c|c|}
\hline Wage & Poor & Rich & Poor - Rich & 4 -to-1 & 1 -to-1 & 4-to-1 - 1-to-1 \\
\cline { 2 - 7 } & 0.07 & 0.03 & $0.04 *$ & 0.07 & 0.03 & 0.04 \\
\hline $\begin{array}{c}\text { Positive } \\
(5 \text { or 10) }\end{array}$ & 0.53 & 0.23 & $0.31^{* * *}$ & 0.44 & 0.33 & $0.12 * * *$ \\
\hline $\begin{array}{c}\text { Positive } \\
\text { Zero }\end{array}$ & $0.46^{* * *}$ & $0.20^{* * *}$ & $\mathbf{0 . 2 6 * * *}$ & $0.37 * * *$ & $0.29 * *$ & $\mathbf{0 . 0 8 *}$ \\
\hline \hline
\end{tabular}

Stars indicate: * significant at $10 \% ; * *$ significant at $5 \% ; * * *$ significant at $1 \%$.

Our second measure of gift exchange is the slope of effort in response to a higher wage. Result 3 speaks to the responsiveness of effort to wage across all wage levels.

\section{Result 3 - In response to an increase in wages, workers increase their effort more when the firm is poor than when it is rich (more gift exchange when the firm is poor)}

Figure 2 shows the mean worker effort by condition and wage, averaging over all observations of all workers. Regardless of the condition, a wage of 0 units by the firm is met with an average effort of nearly 0 units from workers. In addition, on average workers in all conditions return positive effort in response to a positive wage of 5 or 10 units. For the "Poor, 4to-1" and "Poor, 1-to-1" lines we see a positive relationship between wage and effort, replicating previous laboratory gift exchange and trust experiments. In both of these conditions, average effort is increasing in wage. The "Rich 4-to-1" and "Rich, 1-to-1" lines appear to be flatter. 


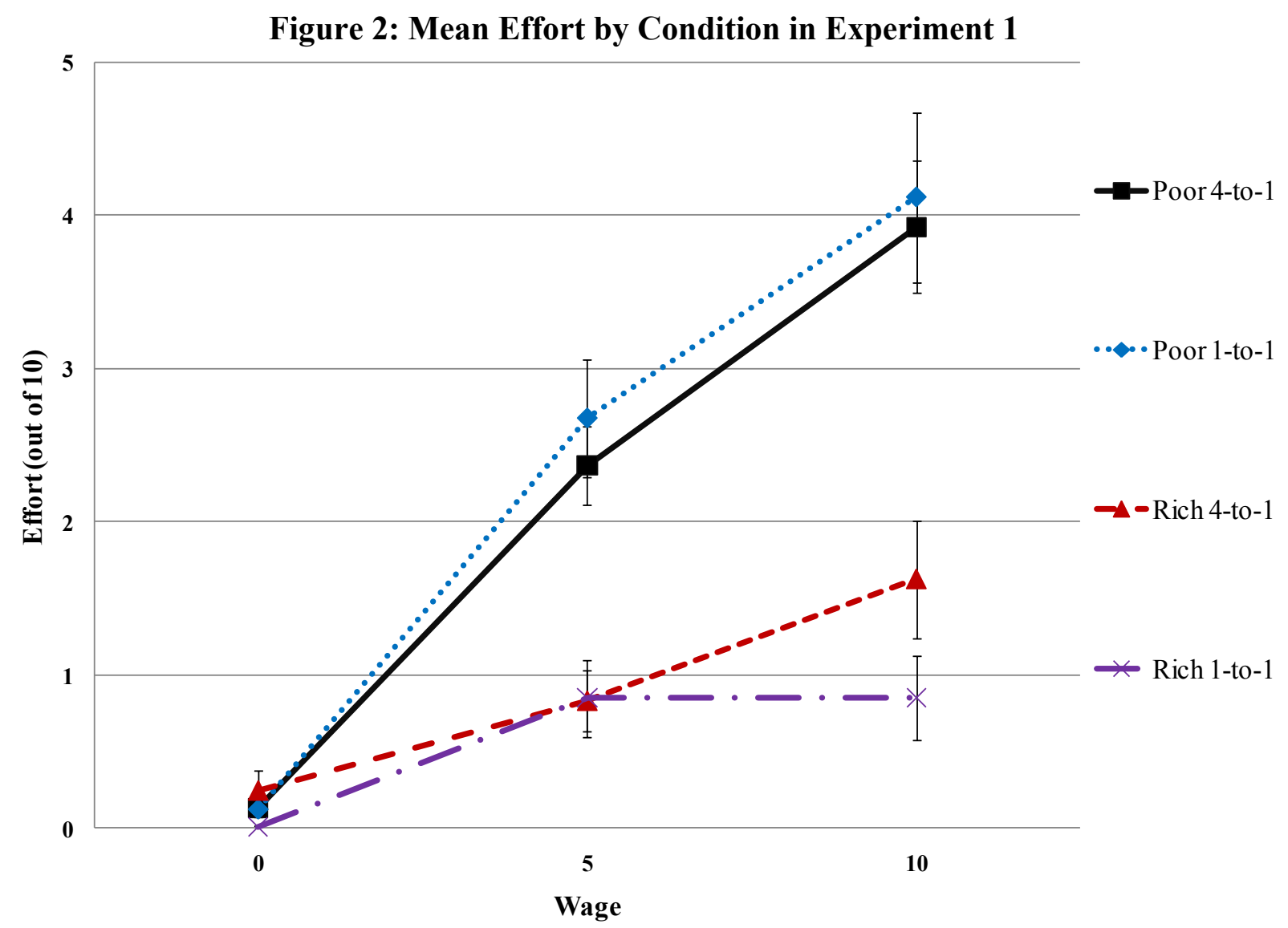

Standard errors for worker effort are displayed around each mean.

Table 3 analyzes the data from Figure 2 in a regression framework, regressing worker effort on wage. The Wage coefficient is positive and significant, indicating that there is a positive relationship between wage paid and subsequent effort the when the firm is poor and effort is not efficient (the omitted category). The Wage*Rich coefficient is statistically significantly negative, which indicates that slope is smaller in magnitude (i.e. flatter) when the firm is rich. The magnitude of the slopes and the strength of these results persist when fixed effects are included — adding worker dummies to allow for different mean levels of effort across workers — in regression (2).

There is some concern that slope estimates may be biased if worker effort choices are censored at 0 or 10 units, the boundaries of the action space. To address this concern, a Tobit specification is used in regressions (3) and (4), accounting for potential censoring at 0 and 10. These regressions estimate coefficients displaying the same pattern as in regressions (1) and (2). 
Slopes are statistically significantly smaller when the firm is rich. We replicate this interaction when effort is efficient for all four specifications.

\section{Table 3: Worker Effort in Experiment 1}

\begin{tabular}{|c|c|c|c|c|}
\hline & $\begin{array}{l}\text { OLS } \\
(1)\end{array}$ & $\begin{array}{l}\text { OLS } \\
(2)\end{array}$ & $\begin{array}{c}\text { Tobit } \\
(3) \\
\end{array}$ & $\begin{array}{c}\text { Tobit } \\
(4) \\
\end{array}$ \\
\hline Wage & $\begin{array}{c}0.403 \\
(0.070)^{* * *}\end{array}$ & $\begin{array}{c}0.391 \\
(0.069)^{* * *}\end{array}$ & $\begin{array}{c}1.390 \\
(0.233)^{* * *}\end{array}$ & $\begin{array}{c}1.323 \\
(0.188)^{* * *}\end{array}$ \\
\hline Wage*Rich & $\begin{array}{c}-0.318 \\
(0.070) * * *\end{array}$ & $\begin{array}{c}-0.284 \\
(0.072)^{* * *}\end{array}$ & $\begin{array}{c}-0.470 \\
(0.240)^{*}\end{array}$ & $\begin{array}{c}-0.413 \\
(0.210)^{* *}\end{array}$ \\
\hline Wage*Efficient & $\begin{array}{l}-0.027 \\
(0.055)\end{array}$ & $\begin{array}{c}0.002 \\
(0.051)\end{array}$ & $\begin{array}{l}-0.066 \\
(0.211)\end{array}$ & $\begin{array}{l}-0.005 \\
(0.191)\end{array}$ \\
\hline Wage*Rich*Efficient & $\begin{array}{c}0.069 \\
(0.078)\end{array}$ & $\begin{array}{l}-0.004 \\
(0.072)\end{array}$ & $\begin{array}{l}-0.104 \\
(0.344)\end{array}$ & $\begin{array}{l}-0.338 \\
(0.286)\end{array}$ \\
\hline Rich & $\begin{array}{l}-0.140 \\
(0.153)\end{array}$ & $\begin{array}{c}-0.275 \\
(0.147)^{*}\end{array}$ & $\begin{array}{c}-4.223 \\
(1.661)^{* *}\end{array}$ & $\begin{array}{c}-4.131 \\
(1.393)^{* * *}\end{array}$ \\
\hline Efficient & $\begin{array}{l}-0.041 \\
(0.167)\end{array}$ & $\begin{array}{l}-0.155 \\
(0.176)\end{array}$ & $\begin{array}{c}0.495 \\
(1.509)\end{array}$ & $\begin{array}{c}0.271 \\
(1.377)\end{array}$ \\
\hline Rich*Efficient & $\begin{array}{c}0.154 \\
(0.245)\end{array}$ & $\begin{array}{c}0.446 \\
(0.246)^{*}\end{array}$ & $\begin{array}{c}2.793 \\
(2.445)\end{array}$ & $\begin{array}{c}3.437 \\
(2.088)\end{array}$ \\
\hline Constant & $\begin{array}{c}0.672 \\
(0.449)\end{array}$ & $\begin{array}{l}-0.097 \\
(0.121)\end{array}$ & $\begin{array}{c}-8.989 \\
(2.498)^{* * *}\end{array}$ & $\begin{array}{c}-7.310 \\
(1.076)^{* * *}\end{array}$ \\
\hline $\begin{array}{l}\text { Observations } \\
\text { R-squared }\end{array}$ & $\begin{array}{l}1056 \\
0.27\end{array}$ & $\begin{array}{l}1056 \\
0.44\end{array}$ & $\begin{array}{l}1056 \\
0.12\end{array}$ & $\begin{array}{l}1056 \\
0.25\end{array}$ \\
\hline $\begin{array}{l}\text { Session Dummies } \\
\text { Worker Dummies }\end{array}$ & $\begin{array}{l}\text { Yes } \\
\text { No }\end{array}$ & $\begin{array}{l}\text { No } \\
\text { Yes }\end{array}$ & $\begin{array}{l}\text { Yes } \\
\text { No }\end{array}$ & $\begin{array}{l}\text { No } \\
\text { Yes }\end{array}$ \\
\hline
\end{tabular}

Standard errors, clustered by worker are in parentheses: * significant at $10 \%$; ** significant at $5 \% ; * * *$ significant at $1 \%$.

Independent Variables: Wage is the wage chosen by the firm $(0,5$ or 10$)$; Rich is a dummy $=1$ if the firm is rich; Efficient is a dummy=1 if the transfer rate is 4-to-1.

The Tobit regressions (3) and (4) have a lower limit at 0 and an upper limit at 10. The Pseudo $\mathrm{R}$-squared is reported.

Workers' effort is not as responsive to higher wages when firms are rich. In the OLS specifications, the slope of effort to wage is about 0.4 when the firm is poor as compared to 0.1 
when the firm is rich. These results suggest that when the firm is rich, the slope of effort to wage is only $25 \%$ of its magnitude when the firm is poor. We do not see the same change in slope associated with the change in efficiency of worker effort.

\section{Discussion of Experiment 1}

Experiment 1 varied two parameters that each may contribute to differences in previously observed gift exchange results. When firms are made rich relative to workers, two measures of gift exchange diminish drastically. When worker effort is not efficient, less gift exchange is observed as well.

In almost all previous laboratory gift exchange environments, the firm is parameterized to be poor relative to the worker at the time of the effort provision; in many field experiments, however, worker effort benefits relatively wealthy employers or managers. To the extent that gift exchange is weaker in some field settings, the difference in treatment effects may be due in part to the different relative wealth comparisons in those field settings and in the lab.

It is worth emphasizing that weaker gift exchange in conditions when the firm is rich does not imply that workers will not engage in gift exchange with relatively rich employers. Workers may respond differently to the wealth of employers in a labor market setting where roles and relative earnings are not randomly assigned. Workers in the labor market may know their employers took additional risks to start a company or that they earned the education or experience necessary to become a manager. Nevertheless, increasing the wealth of the firm in isolation - that is without confounding beliefs about the manager or the intentions associated with given wages - has a negative effect on the likelihood of observing gift exchange and the magnitude of gift exchange observed.

While the efficiency of worker effort did not change the slope of effort with respect to wage, a positive wage leads to a greater increase in the probability of positive effort when worker effort is efficient. This result suggests that fewer workers may engage in gift exchange in settings when effort is not efficient. Consequently, field experiments may not observe gift exchange in settings where worker effort is not efficient. 


\section{Experiment 2: Ability for Workers to Benefit at a Cost to the Firm}

Previous laboratory gift exchange experiments, including Experiment 1, restrict the action space of workers to return nothing or to provide positive effort. In many workplaces and field settings, however, workers have the opportunity to take actions that improve their own outcomes at a cost to the firm. Workers can steal office supplies and equipment, sell trade secrets, or start a competing company and take customers with them. Experiment 2 varies the action space available to workers so that in some conditions workers can take from the firm after they receive their wage. When taking is allowed, workers are less likely to engage in gift exchange.

Experiment 2 uses a similar exogenous shock in a within-subject design to isolate the effect of the increased action space without confounding the intentions of the firm wage. Experiment 2 also includes a between-subject test that expands the action space. In doing so, Experiment 2 addresses and alleviates a concern about experimenter demand effects that might arise from having the same subjects make decisions in different conditions in a within-subject design. The within-subject results from Experiment 2 are replicated in the between-subject design. Workers do not behave differently when they know about the existence of the other action space than when it is never mentioned.

Unlike the manipulations of Experiment 1, the manipulation in Experiment 2 of allowing the worker to take advantage of the firm is not motivated by a desire to explain differences in previous experimental results - no previous studies explicitly allow workers to provide negative effort. Rather, Experiment 2 investigates a parameter, namely the size of the action space, which might be relevant in certain labor market settings. This parameter has also been shown to affect behavior in other contexts. ${ }^{21}$ Results from Experiment 2 provide additional guidance as to when we should expect to see gift exchange in the labor market.

\section{Design of Experiment 2}

Experiment 2 follows Experiment 1 in set up and procedures. Participants play 24 rounds of a bilateral gift exchange game as either a firm or a worker. Each participant is randomly re-

\footnotetext{
${ }^{21}$ Previous laboratory studies have demonstrated that giving individuals the option to take leads subjects to engage in less generous behavior (List 2007; Bardsley 2008). Expanding the action space into the taking domain may have an impact on subjects' willingness to engage in gift exchange.
} 
matched with a player of the other type in each round so that he never plays with the same participant twice in a row. The experiment lasts one hour; participants are paid for one randomly selected round; and average earnings are $\$ 19.14$ per participant inclusive of a $\$ 10$ show up fee. The experiment was conducted using z-Tree 2.1.4 (Fischbacher 2007). ${ }^{22}$

The random treatment utilizes a within-subject design (as in Experiment 1) to test the effect of changing the action space of the worker. At the start of each round in the random treatment, the firm has 30 units and the worker has 35 units. In the first stage, the firm chooses a wage of 0,5 or 10 units, which is multiplied by 4 and transferred to the worker (so the worker receives 0,20 or 40 units). ${ }^{23}$ In the second stage, a random outcome determines whether the worker will choose from the action space that does not allow taking or the action space that does. In the former, the "giving only" condition, the worker can only provide zero effort or provide positive effort (effort can be any whole number of units between 0 and 10). In the latter, the "giving and taking" condition, the worker has an action space that is larger by five units in both directions: he can provide negative effort (by taking up to 5 units), provide zero effort, or provide positive effort (by giving up to 15 units). In the third stage, the worker chooses how much effort to provide. If the worker chooses to provide positive effort (i.e. to give units), the chosen number of effort units is subtracted from his endowment, multiplied by 4, and added to the firm's endowment. Alternatively, if the worker is allowed to and chooses to provide negative effort (i.e. to take units), the chosen number of units is added to his endowment, multiplied by 4 , and subtracted from the firm's endowment. The actions in the taking domain preserve the transfer rate of 4-to-1, so that each unit the worker takes costs the firm 4 units. Increasing the range in

\footnotetext{
${ }^{22}$ The procedures of Experiment 2 differed from the procedures of Experiment 1 slightly. In Experiment 1, subjects had paper instructions (so subjects could refer to them during the experiment) and were asked to record their round-by-round earnings on paper; in Experiment 2, all instructions were shown to subjects on the computer screen and subjects were not asked to keep records of their round-by-round earnings. These changes make the experiment shorter and simpler for subjects. Instructions for Experiment 2 are shown in Appendices B and C.

${ }^{23}$ As in Experiment 1, each experimental unit is worth $\$ 0.20$, the experiment has an initial asymmetry to discourage subjects from thinking of the game as one where they were meant to equalize payoffs, and the scale factor of 4 for the wage was meant to encourage higher wages in the first stage and to allow for sizeable transfers to workers without having to give the firm a significantly larger initial endowment.
} 
both directions preserves the median effort choice (give 5 units) and the mean random action (give 5 units). ${ }^{24}$

Consequently, payoffs to the first and second mover are determined by:

$$
\begin{aligned}
& \pi_{f}=30-w+4 e \\
& \pi_{w}=35+4 w-e
\end{aligned}
$$

where:

$\pi_{f}$ is the firm payoff

$\pi_{w}$ is the worker payoff

$w$ is the wage chosen by the firm where $w \in\{0,5,10\}$

$e$ is the effort provided by the worker, where

$$
\begin{aligned}
& e \in\{0,1, \ldots, 9,10\} \text { in the giving only condition; and } \\
& e \in\{-5,-4, \ldots, 14,15\} \text { in the giving and taking condition }{ }^{25}
\end{aligned}
$$

At the start of random treatment sessions, subjects were told publicly the rules of the game and that the two realizations of the random outcome were equally likely in each round. ${ }^{26}$ In each round, both the firm and worker are informed of the results of the random outcome.

In the random treatment, the wage is chosen before the random outcome is realized. This allows the worker's judgment about the "generosity," "fairness," or "intention" of a particular firm wage to be identical across the two conditions. If firms knew from which action space the worker was choosing before selecting a wage, workers might interpret the wage differently depending on the action space available to the worker. For example, workers might interpret a high wage of 10 units as "being generous" in the giving only condition and as "paying protection" to avoid taking in the giving and taking condition. The within-subject design allows for an identification of the pure effect of the option to take from the firm on how worker effort responds to wage.

\footnotetext{
${ }^{24}$ Increasing the action space in both directions also mitigates a potential experimenter demand effect that might arise if subjects in the random treatment saw an increase in the action space in one direction and thought the experimenter was encouraging behavior in that direction.

${ }^{25}$ A negative action for $e$ is taking, since it increases the worker's payoff by $e$ and decreases the firm's payoff by $4 e$.

${ }^{26}$ All subjects faced the same random drawing realization.
} 
While the random treatment allows an analysis of the pure effect of increasing the worker's action space while keeping firm intentions constant, there is a potential concern that determining the action space after the wage is chosen might induce an experimenter demand effect. Consequently, Experiment 2 includes two additional treatments. One is the giving only treatment, in which firms and workers play a gift exchange game with the "giving only" action space ( 0 to 10$)$ in every round and in which the "giving and taking" action space is never mentioned. The other is the giving and taking treatment, in which firms and workers play the gift exchange game with the "giving and taking" action space (-5 to 15) in every round and in which the "giving only" action space is never mentioned. Comparing effort levels in response to each wage finds no difference in effort whether the "giving only" action space is determined randomly in the random treatment or set for the entire game in the giving only treatment. Similarly there is no difference in effort whether the "giving and taking" condition is determined randomly in the random treatment or set for the whole game in the giving and taking treatment (two-sided t-tests of means and Wilcoxon tests at each wage level, $p>0.1$ for all tests). This generates confidence that the differences in treatment effects observed within subjects are not induced by an experiment demand effect.

The three treatments, the associated action spaces, and the number of observations and participants who participated in each treatment are shown in Figure 3.

Figure 3: Three Treatments of Experiment 2

\begin{tabular}{|c|c|c|c|}
\hline & \multicolumn{2}{|c|}{ Worker Action Space for Effort } \\
\hline & & $\begin{array}{l}\text { Giving Only } \\
(0 \text { to } 10)\end{array}$ & $\begin{array}{l}\text { Giving Only } \\
\text { ( } 0 \text { to } 10)\end{array}$ \\
\hline \multirow{2}{*}{ 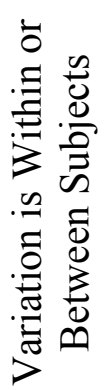 } & $\begin{array}{l}\text { Within } \\
\text { Subjects }\end{array}$ & \multicolumn{2}{|c|}{$\begin{array}{l}\text { Random Treatment } \\
\text { (46 Participants) }\end{array}$} \\
\hline & $\begin{array}{l}\text { Between } \\
\text { Subjects }\end{array}$ & $\begin{array}{c}\text { Giving Only } \\
\text { Treatment } \\
\text { (34 Participants) }\end{array}$ & $\begin{array}{c}\text { Giving and Taking } \\
\text { Treatment } \\
\text { (36 Participants) }\end{array}$ \\
\hline
\end{tabular}


Evidence of gift exchange in Experiment 2 will focus on whether workers are more likely to provide positive effort - or effort above the selfish optimum — in response to a positive wage of 5 or 10 rather than a wage of 0 . The other measure of gift exchange, the slope of effort with response to wage, is harder to interpret when the action space changes, since workers who can give and take have a much large range of effort and so mechanically have more opportunity to vary effort as wages change.

\section{Results of Experiment 2}

The experimental results come from 116 participants, students at Boston-area colleges and universities, who participated in one of six sessions $(n=28,18,18,18,18,16)$ at the Computer Lab for Experimental Research at Harvard Business School. These sessions were conducted six months after Experiment 1 with subjects from the same subject pool. Any subject who participated in Experiment 1 was excluded from participating in Experiment 2.

\section{Result 4 - A positive wage is associated with a smaller increase in the probability of positive effort when taking is allowed (less gift exchange when taking is allowed)}

Table 4 reports the percent of effort choices that are greater than 0 in response to a wage of 0 and a wage of 5 or 10 in each condition. Effort choices are much more likely to be positive when taking is not allowed (Columns 1 and 2) than when taking is allowed (Columns 3 and 4).

Table 4: Probability of Positive Effort (Effort $>0$ ) by Condition and Wage in Experiment 2

\begin{tabular}{|c|c|c|c|c|c|c|c|}
\hline Wage & $\begin{array}{c}\text { Giving } \\
\text { Only }\end{array}$ & $\begin{array}{c}\text { Giving } \\
\text { Only } \\
\text { Random) }\end{array}$ & $\begin{array}{c}\text { Giving \& } \\
\text { Taking }\end{array}$ & $\begin{array}{c}\text { Giving \& } \\
\text { Taking } \\
\text { (Random) }\end{array}$ & $\begin{array}{c}\text { Giving } \\
\text { Only } \\
\text { (Both) }\end{array}$ & $\begin{array}{c}\text { Giving \& } \\
\text { Taking } \\
\text { (Both) }\end{array}$ & $\begin{array}{c}\text { Giving Only } \\
\text { - Giving \& } \\
\text { Taking }\end{array}$ \\
\hline Zero (0) & 0.10 & 0.15 & 0.10 & 0.07 & 0.12 & 0.08 & 0.03 \\
\hline $\begin{array}{c}\text { Positive } \\
(5 \text { or 10) }\end{array}$ & 0.75 & 0.70 & 0.59 & 0.50 & 0.73 & 0.56 & $0.17 * *$ \\
\hline $\begin{array}{c}\text { Positive } \\
- \text { Zero }\end{array}$ & $0.65^{* * *}$ & $0.55^{* * *}$ & $0.49^{* * *}$ & $0.44^{* * *}$ & $0.61 * * *$ & $0.47 * * *$ & $\mathbf{0 . 1 4 *}$ \\
\hline \hline
\end{tabular}

Stars indicate: * significant at $10 \% ; * *$ significant at $5 \% ; * * *$ significant at $1 \%$ 
Combining the within-subject and between-subject data, the probability a worker provides positive effort increases more in response to a positive wage when only giving is allowed (Column 5) than when the worker is also able to take (Column 6). As shown in Column 5 , when only giving is allowed, the probability of positive effort increases 61 percentage points (from $12 \%$ when the wage is 0 to $73 \%$ when the wage is 5 or 10). As shown in Column 6 , when the worker can also take, the probability of positive effort only increases 47 percentage points (from over $8 \%$ to below 56\%). This difference in differences of 14 percentage points - as shown in the bottom row and last column of Table 3 - is statistically significant at the $10 \%$ level ( $\mathrm{p}=0.097, \mathrm{n}=1392$, OLS with standard errors clustered at subject level).

Allowing workers to take advantage of their employer makes it significantly less likely that the workers will engage in gift exchange by providing positive effort in response to a positive wage. However, one might think that when taking is allowed, workers still engage in gift exchange after a positive wage, but that they do so by taking fewer than 5 units (rather than by providing positive effort). In other words, the wider action space might "move the baseline," so that taking fewer than 5 units is considered making a return gift to the firm. When taking is allowed, however, we find less gift exchange by this definition as well.

\section{Result 5 - A positive wage is associated with a smaller increase in the probability of effort above the minimum when taking is allowed (less gift exchange when taking is allowed)}

Table 5 reports the percentage of effort choices that are above the minimum action (i.e. more generous than giving 0 in the giving only conditions and more generous than taking 5 in the giving and taking conditions). The same pattern emerges in Table 5 as did in Table 4 . The percentage of effort choices above the minimum in the giving only conditions (i.e. effort greater than 0) is displayed in Columns 1 and $2 .{ }^{27}$ The percentage of effort choices above the minimum in the giving and taking conditions (i.e. not taking 5 units) is displayed in Columns 3 and 4 .

${ }^{27}$ These left two columns for the giving only conditions are the same in Table 5 as in Table 4, since providing effort above the minimum is the same as providing positive effort in these conditions. 
Table 5: Probability of Effort Above the Minimum (Effort $>0$ in giving only or Effort $>-5$ in giving and taking) by Condition and Wage in Experiment 2

\begin{tabular}{|c|c|c|c|c|c|c|c|}
\hline Wage & $\begin{array}{c}\text { Giving } \\
\text { Only }\end{array}$ & $\begin{array}{c}\text { Giving } \\
\text { Only } \\
\text { (Random) }\end{array}$ & $\begin{array}{c}\text { Giving \& } \\
\text { Taking }\end{array}$ & $\begin{array}{c}\text { Giving \& } \\
\text { Taking } \\
\text { Random) }\end{array}$ & $\begin{array}{c}\text { Giving } \\
\text { Only } \\
\text { (Both) }\end{array}$ & $\begin{array}{c}\text { Giving \& } \\
\text { Taking } \\
\text { (Both) }\end{array}$ & $\begin{array}{c}\text { Giving Only } \\
- \text { Giving \& } \\
\text { Taking }\end{array}$ \\
\hline Zero (0) & 0.10 & 0.15 & 0.26 & 0.18 & 0.12 & 0.23 & -0.11 \\
\hline $\begin{array}{c}\text { Positive } \\
(5 \text { or 10) }\end{array}$ & 0.75 & 0.70 & 0.66 & 0.55 & 0.73 & 0.61 & 0.12 \\
\hline $\begin{array}{c}\text { Positive } \\
\text {-Zero }\end{array}$ & $0.65^{* * *}$ & $0.55^{* * *}$ & $0.40^{* * *}$ & $0.37 * * *$ & $0.61 * * *$ & $0.39 * * *$ & $\mathbf{0 . 2 3 * *}$ \\
\hline \hline
\end{tabular}

Stars indicate: * significant at $10 \% ; * *$ significant at $5 \% ; * * *$ significant at $1 \%$

Combining the within-subject and between-subject data, the probability a worker provides effort above the minimum increases much more in response to a positive wage when only giving is allowed than when the worker is also able to take. As shown in Column 5, when only giving is allowed, the probability of providing effort above the minimum increases 61 percentage points (from $12 \%$ when the wage is 0 to $73 \%$ when the wage is 5 or 10 ). Note that this increase is identical to the increase in probability of providing positive effort, since both measures are identical when only giving is allowed. As shown in Column 6, when the worker can also take, the probability of providing effort above the minimum only increases 39 percentage points (from below $23 \%$ to above $61 \%$ ). This difference in differences of 23 percentage points - as shown in the bottom row and last column of Table 4 - is statistically significant ( $\mathrm{p}=0.010, \mathrm{n}=1392$, OLS with standard errors clustered at subject level).

As the action space changes, a significant number of workers switch from providing positive effort to taking everything — going from acting generously to being entirely selfish. This is happening both between subjects and within subjects. The within-subject results demonstrate that the same worker is responding differently to the same wage, being generous when only giving is allowed and being totally selfish when both giving and taking are allowed. ${ }^{28}$ Direct examination of worker effort choices in the random treatment finds that willingness to switch from being generous to being selfish in response to a large action space is very common.

\footnotetext{
${ }^{28}$ Notice that since only one round in the experiment is paid and because the worker is getting anonymously re-matched in each round, he is not able to provide any sort of insurance by providing effort sometimes and taking sometimes. In addition, the rate of transfer is the same in every condition, so there would be no particular payoff advantage to alternating between providing positive effort and taking.
} 
In total, 12 of 23 workers (52\%) display behavior in which - after receiving the same wage they provide the minimum effort (taking 5 units) when taking is allowed and provide positive effort (giving 1 or more) when only giving is allowed. ${ }^{29}$

\section{Discussion of Experiment 2}

When workers in the lab are allowed to take advantage of the firm that employs them, they are significantly less likely to return positive wages with positive effort. In addition, they are significantly less likely to engage in any sort of reciprocal behavior above the most selfish action possible. These results suggest that gift exchange is less likely to be observed in field environments where workers can take advantage of their employers.

More generally, these results highlight the importance action space can have on observed behavior in laboratory environments. Previous laboratory experiments on gift exchange have only provided subjects with the option to give back to the firm. In labor market settings, workers have other possible actions. Even if they cannot take advantage of the firm, they may be able to take an action on some other dimension. Workers might display goodwill towards their employer by taking actions outside of the workplace (e.g. talking about how great the firm or its products are, referring friends to work for their firm, or otherwise helping recruit new employees). The opportunity to take actions on multiple dimensions may influence how workers respond to gifts from a firm. In the lab, actions are primarily restricted to the dimension of providing effort, but future experiments might vary whether laboratory subjects are allowed to take actions on different dimensions. The effect of introducing multiple dimensions for action on gift exchange remains an open question.

\section{Conclusion}

The ongoing debate about the relative merits of laboratory and field experiments has focused on differences between the traditional laboratory experiment and the traditional field experiment. However, there are many parameters that vary between a particular lab setting and a

\footnotetext{
${ }^{29}$ Of the 23 workers in the random treatment, 4 workers (17\%) always took 5 units in the giving and taking condition after a wage to which they provided positive effort at least once in the giving only condition. In addition, 10 workers (43\%) took 5 units at least once in response to a wage to which they always provided positive effort in the giving only condition. Two workers satisfied both conditions: in the giving condition, they always provided positive effort in response to a wage to which they always took 5 units in the giving and taking condition.
} 
particular field setting that may contribute to the variation in treatment effects. Understanding the impact of each of these parameters can help illuminate the underlying mechanisms driving treatment effects and allow researchers to make better predictions about when and where such treatment effects will be observed.

The two experiments in this paper focus on gift exchange. Previous experimental studies investigating the willingness of subjects to engage in gift exchange have found results that vary significantly across laboratory and field environments. Many laboratory experiments observe that workers provide more effort in response to a positive wage shock, while this treatment effect is significantly weaker or completely absent in many field environments. Perhaps as a consequence, gift exchange has been a central example in the debate about the relative merits of laboratory and field experiments.

In this paper, Experiment 1 investigated two parameters that differ systematically between many previous laboratory and field experiments. Experiment 1 finds that workers asked to provide effort to benefit relatively rich firm do not engage in gift exchange as readily. When worker effort is not efficient, a smaller percentage of workers return positive effort in response to a positive wage. These parameters differences may generate some of the variation in previous experimental results across the lab and field. Experiment 2 demonstrated that allowing workers to take advantage of the firm also leads workers to be less likely to engage in gift exchange.

This paper has demonstrated a particular way in which field experiments and laboratory experiments are complements in the production of knowledge. In the lab, an experimenter can create a simplified model of the world and investigate treatment effects there. If this simplified setting omits important features of other environments of interest, the treatment effects estimated in the lab might fail to generalize to those other environments. A particular field setting will be complex and will differ from a particular laboratory setting on many dimensions. If treatment effects differ across these lab and field settings, any number of differences may be responsible for the difference in treatment effects. Investigating the impact of each difference has the potential to heighten understanding of the underlying mechanisms generating the treatment effects. This investigation of what factors are generating the difference in treatment effects can occur in the laboratory (as presented here) or in the field. In this way, researchers will come to understand when and why an economic environment of interest will generate a treatment effect similar to the one estimated in the lab or to the one estimated in the field. 


\section{References}

Akerlof, George. 1982. "Labor Contracts as Partial Gift-Exchange.” Quarterly Journal of Economics, 97: 543-569.

Akerlof, George. 1984. "Gift Exchange and Efficiency-Wage Theory: Four Views." American Economic Review, 74: 79-83.

Akerlof, George and Janet Yellen. 1990. "The Fair Wage-Effort Hypothesis and Unemployment." Quarterly Journal of Economics, 105: 255-283.

Al-Ubaydli, Omar and John A. List. 2012. "On The Generalizability of Experimental Results in Economics." Fréchette, Guillaume and Andrew Schotter (editors) The Methods of Modern Experimental Economics, Oxford University Press.

Bardsley, Nicholas. 2008. “Dictator Game Giving: Altruism or Artefact?” Experimental Economics, 11: 122-133.

Bellemare, Charles and Bruce Shearer. 2009. "Gift giving and worker productivity: Evidence from a firm-level experiment." Games and Economic Behavior, 67: 233-244.

Berg, Joyce, John Dickhaut and Kevin McCabe. 1995. "Trust, Reciprocity, and Social History." Games and Economic Behavior, 10: 122-142.

Brandts, Jordi and Gary Charness. 2004. "Do Labour Market Conditions Affect Gift Exchange? Some Experimental Evidence.” The Economic Journal, 114: 684-708.

Camerer, Colin. 2012. "The promise and success of lab-field generalizability in experimental economics: A critical reply to Levitt and List." Fréchette, Guillaume and Andrew Schotter (editors) The Methods of Modern Experimental Economics, Oxford University Press.

Charness, Gary. 2000. "Responsibility and effort in an experimental labor market." Journal of Economic Behavior \& Organization, 42: 375-384.

Charness, Gary and Matthew Rabin. 2002. "Understanding Social Preferences with Simple Tests.” Quarterly Journal of Economics, 17: 817-869.

Charness, Gary. 2004. "Attribution and Reciprocity in an Experimental Labor Market." Journal of Labor Economics, 22: 665-688.

Charness, Gary, Guillaume Frechette and John Kagel. 2004. "How robust is laboratory gift exchange?” Experimental Economics, 7: 189-205.

Charness, Gary and David Levine. 2007. "Intention and Stochastic Outcomes: An Experimental Study.” The Economic Journal, 117: 1051-1072. 
Cohn, Alain, Ernst Fehr and Lorenz Goette. 2008. "Fairness and Effort: Evidence from a Field Experiment." Working Paper.

Dawes, Robyn M. and Richard H. Thaler. 1988. “Anomalies: Cooperation.” Journal of Economic Perspectives, 2: 187-198.

Englmaier, Florian and Stephen Leider. 2012. "Managerial Payoff and Gift Exchange in the Field." Working Paper.

Falk, Armin and Urs Fischbacher. 2006. "A theory of reciprocity." Games and Economic Behavior, 54: 293-315.

Falk, Armin and James Heckman. 2009. "Lab Experiments Are a Major Source of Knowledge in the Social Sciences." Science, 326: 535-538.

Fehr, Ernst, Simon Gachter and Georg Kirchsteiger. 1997. "Reciprocity as a Contract Enforcement Device: Experimental Evidence.” Econometrica, 65: 833-860.

Fehr, Ernst, Lorenz Goette, and Christian Zehnder. 2009. "A Behavioral Account of the Labor Market: The Role of Fairness Concerns." Annual Review of Economics, 1: 355.

Fehr, Ernst, Erich Kirchler, Andreas Weichbold, and Simon Gachter. 1998. "When Social Forces Overpower Competition: Gift Exchange in Experimental Labor Markets.” Journal of Labor Economics, 16: 324-351.

Fehr, Ernst, Georg Kirchsteiger and Arno Riedl. 1993. "Does Fairness Prevent Market Clearing? An Experimental Investigation.” Quarterly Journal of Economics, 108: 437-459.

Fehr, Ernst and Klaus Schmidt. 1999. "A Theory of Fairness, Competition, and Cooperation." Quarterly Journal of Economics, 114: 817-868.

Fischbacher, Urs. 2007. "z-Tree: Zurich Toolbox for Ready-made Economic Experiments." Experimental Economics, 10: 171-178.

Gachter, Simon and Armin Falk. 2002. "Reputation and Reciprocity: Consequences for the Labour Relation" Scandinavian Journal of Economics, 104(1): 1-26.

Gneezy, Uri and John A. List. 2006. "Putting Behavioral Economics to Work: Field Evidence of Gift Exchange.” Econometrica, 74: 1365-1384.

Hannan, R. Lynn, John H. Kagel and Donald V. Moser. 2002. "Partial Gift Exchange in an Experimental Labor Market: Impact of Subject Population Differences, Productivity Differences, and Effort Requests on Behavior." Journal of Labor Economics, 20: 923951. 
Harrison, Glenn W. and John A. List. 2004. "Field Experiments." Journal of Economic Literature, 42: 1009-1055.

Hennig-Schmidt, Heike, Bettina Rockenbach, and Abdolkarim Sadrieh. 2010. "In Search of Workers' Real Effort Reciprocity-A Field and a Laboratory Experiment." Journal of the European Economic Association, 8(4): 817-837.

Kagel, John H. 2009. "Laboratory Experiments: The Lab in Relationship to Field Experiments, Field Data and Economic Theory" Fréchette, Guillaume and Andrew Schotter (editors) The Methods of Modern Experimental Economics, Oxford University Press.

Kessler, Judd B. and Lise Vesterlund. 2012. "The external validity of laboratory experiments: Qualitative rather than quantitative effects" Fréchette, Guillaume and Andrew Schotter (editors) The Methods of Modern Experimental Economics, Oxford University Press.

Kube, Sebastian, Michel Andre Marechal and Clemens Puppe. 2011. "The Currency of Reciprocity: Gift Exchange in the Workplace." American Economic Review, 102(4): 1644-62.

Levitt, Steven D. and John A. List. 2006. "What do laboratory experiments tell us about the real world?" Working Paper.

Levitt, Stephen D. and John A. List. 2007a. "What Do Laboratory Experiments Measuring Social Preferences Tell Us About the Real World?" Journal of Economic Perspectives, 21: 153174.

Levitt, Stephen D. and John A. List. 2007b. "Viewpoint: On the generalizability of lab behaviour to the field." Canadian Journal of Economics, 40: 347-370.

Levitt, Steven D. and John A. List. 2008. "Economics. Homo economicus evolves." Science 319: 909-910.

List, John A. 2006. "The Behavioralist Meets the Market: Measuring Social Preferences and Reputation Effects in Actual Transactions.” Journal of Political Economy, 114: 1-37.

List, John A. 2007. "On the Interpretation of Giving in Dictator Games." Journal of Political Economy, 115: 482-493.

List, John A. and David Reiley. 2008. "Field experiments." Steven N. Durlauf and Lawrence E. Blume (editors) The New Palgrave Dictionary of Economics, Palgrave Macmillan Publishing.

Roth, Alvin E. 2008. "What have we learned from market design?” Economic Journal, 118: 285-310. 
Roth, Alvin E. 2012. "Is Experimental Economics Living Up to Its Promise?" Fréchette, Guillaume and Andrew Schotter (editors) The Methods of Modern Experimental Economics, Oxford University Press.

Slonim, Robert, Carmen Wang, Ellen Garbarino, and Danielle Merrett. 2012. "Opting-in: Participation Bias in Economic Experiments.” Working paper.

Xiao, Erte and Cristina Bicchieri. 2010. "When Equality Trumps Reciprocity." Journal of Economic Psychology, 31(3): 456. 


\title{
Appendix A: Experiment 1 Instructions
}

\section{PLEASE DO NOT TALK TO ANY OTHER PARTICIPANT FOR THE REMAINDER OF THE SESSION.}

\author{
IF YOU HAVE A QUESTION AT ANY TIME, PLEASE RAISE YOUR HAND
}

You are a First Mover

\section{WELCOME}

In this experiment, you will play 24 rounds of a decision making game. The experiment involves First Movers and Second Movers. Your role is indicated at the top of this page. You will remain in this role for all 24 rounds.

You will be paid based on your performance in one randomly selected round. In the instructions below, each experimental unit is worth $\$ 0.20$. Money earned will be paid to you in cash at the end of the experiment.

\section{EXPERIMENT STRUCTURE}

In each round, you will play a decision making game via the computer with a randomly paired participant of the other type. You will be randomly paired with a new participant in each round, so that you never interact with the same participant more than once in a row.

Your identity, and the identity of all other participants, will remain anonymous.

\section{ROUND INSTRUCTIONS}

At the start of each round:

There will be 30 units in the First Mover's endowment.

There will be 35 units in the Second Mover's endowment.

Each round will have three stages.

Stage 1) The First Mover will have the option to transfer either 0 or 5 or 10 units from his or her endowment to the Second Mover.

Any units transferred will be multiplied by 4 and added to the Second Mover's endowment. So, if the First Mover transfers:

- 0 units, then 0 units will be added to the Second Mover's endowment

- 5 units, then 20 units will be added to the Second Mover's endowment

- 10 units, then 40 units will be added to the Second Mover's endowment 
Stage 2) One of four random outcomes will occur. The four outcomes are listed below. Each has a probability of $25 \%$, so all are equally likely.

- 60 units will be added to the First Mover's endowment and future transfers in this round will be multiplied by 1 .

- 60 units will be added to the First Mover's endowment and future transfers in this round will be multiplied by 4 .

- 0 units will be added to the First Mover's endowment and future transfers in this round will be multiplied by 1 .

- 0 units will be added to the First Mover's endowment and future transfers in this round will be multiplied by 4 .

Both the First Mover and the Second Mover will be informed of the random outcome.

Stage 3) The Second Mover will have the option to transfer any whole number of units from 0 to 10 from his or her endowment to the First Mover.

The number of units transferred will be subtracted from the Second Mover's endowment. The number of units transferred will then be multiplied by 1 or 4 , as determined by the random outcome, and this number will be added to the First Mover's endowment.

This concludes a round.

At the end of each round, record the final endowment for that round on your payment sheet in the appropriate box.

You will then play the same game with a new participant. New transfers will be made and one of the four random outcomes will occur, independent of previous results.

You will never interact with the same participant more than once in a row. 


\section{EARNINGS}

You will play 24 independent rounds over the course of the experiment. At the end of the experiment, you will be compensated based on the results of one randomly selected round.

The US\$ value of your earnings in the randomly selected round is equal to:

$\$ 0.20 *$ (\# of units in your final endowment at the end of the randomly selected round)

This amount will be added to your show up fee and paid to you in cash at the end of the experiment.

Your decisions will remain private information, and no other participants will know the decisions you made during the experiment or how much you have earned. 


\section{Appendix B: Experiment 2 Instructions (Random Treatment)}

PLEASE DO NOT TALK TO ANY OTHER PARTICIPANT FOR THE REMAINDER OF THE SESSION.

IF YOU HAVE A QUESTION AT ANY TIME, PLEASE RAISE YOUR HAND

\section{Experiment Instructions 1 of 8}

In this experiment, you will play 24 rounds of a decision making game.

The experiment involves First Movers and Second Movers.

You are a First Mover. You will remain in this role for all 24 rounds.

You will be paid based on your performance in one randomly selected round.

In the instructions below, each experimental unit is worth $\$ 0.20$.

Money earned will be paid to you in cash at the end of the experiment.

\section{Experiment Instructions 2 of 8}

In each round, you will play a decision making game via the computer with a randomly paired participant of the other type.

You will be randomly paired with a new participant in each round, so that you never interact with the same participant twice in a row.

Your identity, and the identity of all other participants, will remain anonymous.

\section{Experiment Instructions 3 of 8}

\section{Round Instructions}

At the start of each round:

There will be 30 units in the First Mover's endowment.

There will be 35 units in the Second Mover's endowment.

Each round will have three stages. 


\section{Experiment Instructions 4 of 8}

\section{Stage 1}

The First Mover will have the option to transfer either 0 or 5 or 10 units from his or her endowment to the Second Mover.

Any units transferred will be multiplied by 4 and added to the Second Mover's endowment.

So, if the First Mover transfers:

- 0 units, then 0 units will be added to the Second Mover's endowment

- 5 units, then 20 units will be added to the Second Mover's endowment

- 10 units, then 40 units will be added to the Second Mover's endowment

\section{Experiment Instructions 5 of 8}

\section{Stage 2}

The computer will randomly choose one of the two environments below. Both have a probability of $50 \%$, so they are equally likely.

- Environment A

- Environment B

Both the First Mover and the Second Mover will be informed of the environment chosen. 


\section{Experiment Instructions 6 of 8}

\section{Stage 3: Environment A}

\section{If the computer randomly chooses Environment $A$ :}

The Second Mover will have the option to transfer

- From the Second Mover to the First Mover OR

- From the First Mover to the Second Mover

If the Second Mover decides to transfer from the Second Mover to the First Mover, he or she can transfer any whole number of units from 0 to 15 .

This number of units will be subtracted from the Second Mover's endowment.

The number of units will then be multiplied by 4 , and this number will be added to the First Mover's endowment.

If the Second Mover decides to transfer from the First Mover to the Second Mover, he or she can transfer any whole number of units from 1 to 5 .

This number of units will be added to the Second Mover's endowment.

The number of units will then be multiplied by 4 , and this number will be subtracted from the First Mover's endowment.

\section{Experiment Instructions 7 of 8}

\section{Stage 3: Environment B}

If the computer randomly chooses Environment B:

The Second Mover will have the option to transfer

- From the Second Mover to the First Mover

The Second Mover can transfer any whole number of units from 0 to 10 .

This number of units will be subtracted from the Second Mover's endowment.

The number of units will then be multiplied 4 , and this number will be added to the First Mover's endowment. 


\section{Additional Materials: Not for Publication}

\section{Experiment Instructions 8 of 8}

\section{Earnings}

You will play 24 independent rounds over the course of the experiment.

At the end of the experiment, you will be compensated based on the results of one randomly selected round.

The US\$ value of your earnings in the randomly selected round is equal to:

$\$ 0.20 *$ (\# of units in your final endowment at the end of the randomly selected round)

This amount will be added to your show up fee and paid to you in cash at the end of the experiment.

Your decisions will remain private information, and no other participants will know the decisions you made during the experiment or how much you have earned.

\{Note: This screen was shown to first movers only.\}

You now have the option to transfer part of your endowment to the Second Mover you are paired with this round.

Please choose either 0,5 , or 10 . This amount will be subtracted from your endowment, multiplied by 4 and added to the Second Mover's endowment.

The Second Mover's endowment: 35

Your Current Endowment: 30

The amount you transfer: [INPUT]

\{Note: An interim screen was shown to each first mover and each second mover with the results of the first stage transfer from that first mover to that second mover.\}

\{Note: A screen was shown to each first mover and each second mover showing the results of the random outcome, in this case generating the giving and taking condition.\}

The computer chose Environment A. 
\{Note: This screen was shown to second movers only. The values $X$ and $Y$ were determined by the first stage transfer. This is the decision screen for the giving and taking condition.\}

You must now choose the direction of the transfer and how many units to transfer.

If you want to transfer from your endowment, please choose a whole number between 0 and 15 . This amount will be subtracted from your endowment. This amount will also be multiplied by 4 and added to the First Mover's endowment.

If you want to transfer to your endowment, please choose a whole number between 1 and 5 . This amount will be added to your endowment. This amount will also be multiplied by 4 and subtracted from the First Mover's endowment.

The First Mover's endowment: [X]

Your current endowment: [Y]

Choose the direction of the transfer: [RADIO BUTTON] from your endowment [RADIO BUTTON] to your endowment

Number of units to transfer: [INPUT] 


\section{Appendix C: Experiment 2 Instructions (Giving Only Treatment) \\ PLEASE DO NOT TALK TO ANY OTHER PARTICIPANT FOR THE REMAINDER OF THE SESSION.}

IF YOU HAVE A QUESTION AT ANY TIME, PLEASE RAISE YOUR HAND

\section{Experiment Instructions 1 of 6}

In this experiment, you will play 24 rounds of a decision making game.

The experiment involves First Movers and Second Movers.

You are a First Mover. You will remain in this role for all 24 rounds.

You will be paid based on your performance in one randomly selected round.

In the instructions below, each experimental unit is worth $\$ 0.20$.

Money earned will be paid to you in cash at the end of the experiment.

\section{Experiment Instructions 2 of 6}

In each round, you will play a decision making game via the computer with a randomly paired participant of the other type.

You will be randomly paired with a new participant in each round, so that you never interact with the same participant twice in a row.

Your identity, and the identity of all other participants, will remain anonymous.

\section{Experiment Instructions 3 of 6}

\section{Round Instructions}

At the start of each round:

There will be 30 units in the First Mover's endowment.

There will be 35 units in the Second Mover's endowment.

Each round will have two stages. 


\section{Experiment Instructions 4 of 6}

\section{Stage 1}

The First Mover will have the option to transfer either 0 or 5 or 10 units from his or her endowment to the Second Mover.

Any units transferred will be multiplied by 4 and added to the Second Mover's endowment.

So, if the First Mover transfers:

- 0 units, then 0 units will be added to the Second Mover's endowment

- 5 units, then 20 units will be added to the Second Mover's endowment

- 10 units, then 40 units will be added to the Second Mover's endowment

\section{Experiment Instructions 5 of 6}

\section{Stage 2}

The Second Mover will have the option to transfer

- From the Second Mover to the First Mover

The Second Mover can transfer any whole number of units from 0 to 10 .

This number of units will be subtracted from the Second Mover's endowment.

The number of units will then be multiplied 4, and this number will be added to the First Mover's endowment.

\section{Experiment Instructions 6 of 6 \\ Earnings}

You will play 24 independent rounds over the course of the experiment.

At the end of the experiment, you will be compensated based on the results of one randomly selected round.

The US\$ value of your earnings in the randomly selected round is equal to:

$\$ 0.20 *$ (\# of units in your final endowment at the end of the randomly selected round)

This amount will be added to your show up fee and paid to you in cash at the end of the experiment.

Your decisions will remain private information, and no other participants will know the decisions you made during the experiment or how much you have earned 


\section{Additional Materials: Not for Publication}

\{Note: This screen was shown to first movers only.\}

You now have the option to transfer part of your endowment to the Second Mover you are paired with this round.

Please choose either 0,5 , or 10 . This amount will be subtracted from your endowment, multiplied by 4 and added to the Second Mover's endowment.

The Second Mover's endowment: 35

Your Current Endowment: 30

The amount you transfer: [INPUT]

\{Note: An interim screen was shown to each first mover and each second mover with the results of the first stage transfer from that first mover to that second mover.\}

\{Note: This screen was shown to second movers only. The values $X$ and $Y$ were determined by the first stage transfer.\}

You must now choose how many units to transfer.

This amount will be subtracted from your endowment. This amount will also be multiplied by 4 and added to the First Mover's endowment.

The First Mover's endowment: [X]

Your current endowment: [Y]

Number of units to transfer: [INPUT] 